\title{
Optimization of diaryl amine derivatives as kinesin spindle protein inhibitors.
}

\section{$\operatorname{AUTHOR}(\mathrm{S})$ :}

Takeuchi, Tomoki; Oishi, Shinya; Kaneda, Masato; Misu, Ryosuke; Ohno, Hiroaki; Sawada, Jun-ichi; Asai, Akira; Nakamura, Shinya; Nakanishi, Isao; Fujii, Nobutaka

\section{CITATION:}

Takeuchi, Tomoki ... [et al]. Optimization of diaryl amine derivatives as kinesin spindle protein inhibitors.. Bioorganic \& medicinal chemistry 2014, 22(12): 3171-3179

\section{ISSUE DATE:}

2014-06-15

\section{URL:}

http://hdl.handle.net/2433/189466

\section{RIGHT:}

(C) 2014 Elsevier Ltd.; This is not the published version. Please cite only the published version.; この論文は出版社版でありません。引用の際に は出版社版をご確認ご利用ください。 


\section{Optimization of Diaryl Amine Derivatives as Kinesin Spindle Protein Inhibitors}

Tomoki Takeuchi ${ }^{\text {a }}$, Shinya Oishi ${ }^{\mathrm{a}, *}$, Masato Kaneda ${ }^{\mathrm{a}}$, Ryosuke Misu ${ }^{\mathrm{a}}$, Hiroaki Ohno ${ }^{\mathrm{a}}$, Jun-ichi Sawada $^{\mathrm{b}}$, Akira Asai ${ }^{\mathrm{b}}$, Shinya Nakamura ${ }^{\mathrm{c}}$, Isao Nakanishic ${ }^{\mathrm{c}}$, Nobutaka Fujii ${ }^{\mathrm{a}, *}$

${ }^{a}$ Graduate School of Pharmaceutical Sciences, Kyoto University, Sakyo-ku, Kyoto 606-8501, Japan

${ }^{\mathrm{b}}$ Graduate School of Pharmaceutical Sciences, University of Shizuoka, Suruga-ku, Shizuoka 422-8526, Japan

${ }^{c}$ Faculty of Pharmacy, Kinki University, 3-4-1 Kowakae, Higashi-osaka 577-8502, Japan

\section{Corresponding Authors:}

Shinya Oishi, Ph.D. and Nobutaka Fujii, Ph.D.

Graduate School of Pharmaceutical Sciences

Kyoto University

Sakyo-ku, Kyoto, 606-8501, Japan

Tel: +81-75-753-4551; Fax: +81-75-753-4570,

E-mail (S.O.): soishi@pharm.kyoto-u.ac.jp; E-mail (N.F.): nfujii@pharm.kyoto-u.ac.jp 


\begin{abstract}
Structure-activity relationship studies of diaryl amine-type KSP inhibitors were carried out. Diaryl amine derivatives with a pyridine ring or urea group were less active when compared with the parent carboline and carbazole derivatives. Optimization studies of a lactam-fused diphenylamine-type KSP inhibitor revealed that the aniline $\mathrm{NH}$ group and 3-CF3 phenyl group were indispensable for potent KSP inhibition. Modification with a seven-membered lactam-fused phenyl group and a 4-(trifluoromethyl)pyridin-2-yl group improved aqueous solubility while maintaining potent KSP inhibitory activity. From these studies, we identified novel diaryl amine-type KSP inhibitors with a favorable balance of potency and solubility.
\end{abstract}

Keywords: diaryl amine, kinesin spindle protein, aqueous solubility

\title{
1. Introduction
}

Kinesins constitute a superfamily of molecular motor proteins to move along microtubules. ${ }^{1}$ Mitotic kinesins are involved in cell division. ${ }^{2}$ Non-mitotic kinesins are principally involved in intracellular transport of organelles and vesicles. ${ }^{3}$ The kinesin spindle protein (KSP; also known as Eg5) is the mitotic kinesin that belongs to the kinesin-5 family. The structure of KSP is comprised of three parts: an N-terminal motor domain, a central $\alpha$-helical coiled coil stalk domain, and a C-terminal tail domain. ${ }^{4}$ The $\mathrm{N}$-terminal motor domain contains a catalytic site for ATP hydrolysis and microtubule binding region. KSP moves toward the plus end of the microtubule, just like other kinesins with an N-terminal motor domain, using the energy generated from the hydrolysis of ATP. ${ }^{5}$ The KSP movement is required for centrosome separation and bipolar spindle formation during cell division. Inhibition of KSP leads to mitotic arrest in the prometaphase with the formation of the monopolar spindle and subsequent apoptotic cell death. ${ }^{6-9}$ Therefore, KSP inhibitors are 
expected to be favorable agents for cancer chemotherapy without neurotoxic side effects. ${ }^{10-13}$

Recently, we reported that carbazole derivative 1 with the 2-CF3 group showed potent KSP inhibitory activity (Figure 1). ${ }^{14}$ Carbazole derivatives, with a lactam ring (2) or urea group (4c), and the $\beta$-carboline derivative 3a were also identified as highly potent KSP inhibitors by structure-activity relationship studies of $\mathbf{1} .^{15}$ However, these inhibitors exhibited limited solubility in the aqueous solvents employed for in vivo studies. To satisfy the potent inhibitory activity requirements as well as better solubility in aqueous solution, we have designed diphenylamine derivatives such as $\mathbf{5 a}$ by modification of the planar carbazole-type inhibitor $2 .{ }^{16}$ Diphenylamine 5a exhibited better solubility than carbazole $\mathbf{2}$ while maintaining potent KSP inhibitory activity. Structural analysis by single crystal X-ray diffraction studies and free energy calculations demonstrated that the improved solubility of $\mathbf{5 a}$ is attributed to fewer van der Waals interactions in the crystal packing, as well as a hydrogen-bond acceptor nitrogen in the aniline moiety for favorable solvation. Interestingly, compound $\mathbf{5 a}$ possibly binds to the interface of the $\alpha 4$ and $\alpha 6$ of KSP in an ATP-competitive manner, whereas most KSP inhibitors (e.g., monastrol, $S$-trityl-L-cysteine) bind to the allosteric pocket formed by helices $\alpha 2, \alpha 3$ and loop L5 to show ATP-uncompetitive behavior. ${ }^{17-19}$ Replacing the right-hand 3- $\mathrm{CF}_{3}$-phenyl group in 5a with a pyridine ring provided a more soluble KSP inhibitor 6; however, this compound showed slightly lower potency than $\mathbf{5 a} .{ }^{16}$ In this article, we describe the structure-activity relationship study for novel diaryl amine-type KSP inhibitors with high potency and aqueous solubility. For this purpose, we performed: (i) modification of ring-fused indoles such as $\mathbf{3 a}$ and $\mathbf{4 c}$ using the same approach employed for the development of 5a and (ii) intensive optimization studies of diphenylamine $\mathbf{5 a}$.

\section{Results and discussion}

\subsection{Investigation of diaryl amine-type KSP inhibitors by modification of ring-fused}




\section{scaffolds}

We speculated that the poor solubility of carboline and carbazole derivatives would be attributable to the significant intermolecular interactions in the crystals (e.g., $\pi-\pi$ stacking interactions) as seen for compound $2 .{ }^{16}$ To disrupt the possible crystal packing of compounds 3a and 4c, the design of less planar analogs was expected to be a promising approach. ${ }^{20}$ Therefore, we designed diaryl amine derivatives $\mathbf{7}$ and $\mathbf{8}$, in which the pyrrole $\mathrm{C}-\mathrm{C}$ bond in the central part of carbolines 3 and carbazoles 4 was cleaved (Figure 2). Diaryl amines 7a,b with a pyridine ring were designed based on carbolines 3a,b with potent KSP inhibitory activity (Figure 2A). Diphenylamines 8a-f with a nitro, amino or urea group at the 3- or 4-position on the left-hand phenyl ring were similarly investigated, which represent the cleaved analogs of carbazoles 4b-f (Figure 2B). Diaryl amine derivatives 7a,b and 8a,d were prepared by palladium-catalyzed $N$-arylation using aryl bromides $\mathbf{9}$ and substituted anilines $\mathbf{1 0}$ (Scheme 1). ${ }^{21}$ For the preparation of compounds $\mathbf{8 c}, \mathbf{f}$ with a urea group, nitro derivatives $\mathbf{8 a}, \mathbf{d}$ were reduced to the corresponding amines $8 \mathbf{b}, \mathbf{e}$ using $\mathrm{Pd} / \mathrm{C}$ and ammonium formate, which were converted to the expected compounds $8 \mathbf{c}, \mathbf{f}$ by KOCN.

First, KSP inhibitory activity of compounds $\mathbf{7 a}, \mathbf{b}$, with a pyridine ring in the left-hand part, was comparatively assessed with the parent carboline-type inhibitors 3a,b (Table 1). Unfortunately, the cleavage of the pyrrole $\mathrm{C}-\mathrm{C}$ bond in carboline led to loss of KSP ATPase inhibitory activity at $6.3 \mu \mathrm{M}$. The solubility of these compounds was evaluated by a thermodynamic method. ${ }^{22}$ A mixture of EtOH-phosphate buffer (pH 7.4) (1:1) [50\% EtOH] and phosphate buffer ( $\mathrm{pH} 7.4$ ) were employed as aqueous media. ${ }^{22}$ In these solutions, the parent carbazole-type inhibitor 1 was moderately soluble $(0.424 \mathrm{mg} / \mathrm{mL})$ and insoluble $(<1$ $\mu \mathrm{g} / \mathrm{mL}$ ), respectively. $N$-(Pyridin-3-yl)amine 7a showed the anticipated improvement in thermodynamic solubility, being 30 times more soluble in $50 \%$ EtOH $(14.3 \mathrm{mg} / \mathrm{mL})$ compared with the corresponding carboline 3a. $N$-(Pyridin-4-yl)amine $7 \mathbf{b}$ also exhibited 
approximately 14 times greater solubility in $50 \% \mathrm{EtOH}(24.0 \mathrm{mg} / \mathrm{mL})$ than the parent carboline 3b. Of note, compound $\mathbf{7 b}$ had moderate solubility $(264 \mu \mathrm{g} / \mathrm{mL})$ even in phosphate buffer, which was 80 times or more soluble compared with $\mathbf{3 b}$ and $\mathbf{3 a}$, respectively. Although these pyridinylamine derivatives $\mathbf{7 a}, \mathbf{b}$ were inert in KSP inhibition, it was suggested that cleavage of the pyrrole $\mathrm{C}-\mathrm{C}$ bond in carboline and carbazole derivatives could be a promising approach to improve the solubility in aqueous solution.

Diphenylamine derivatives 8a-f with a nitro, amino or urea group at the 3- or 4-position on the left-hand phenyl group were next examined (Table 2). The 3-substituted anilines 8a-c showed no KSP inhibitory activity at $6.3 \mu \mathrm{M}$. Among the 4-substituted analogs, compound $\mathbf{8 f}$ with a urea group exhibited moderate inhibitory activity $\left(\mathrm{IC}_{50}=0.39 \mu \mathrm{M}\right)$, while compounds $\mathbf{8 d , e ~ w i t h ~ a ~ n i t r o ~ o r ~ a m i n o ~ g r o u p ~ h a d ~ w e a k ~ o r ~ n o ~ p o t e n c y . ~ T h e ~ p o t e n c y ~ o f ~} \mathbf{8 f}$ was approximately three times lower than that of the parent carbazole $\mathbf{4 f}$.

\subsection{Optimization studies of lactam-fused diaryl amine-type KSP inhibitors}

Next, we investigated the structure-activity relationship and the further refinement of $\mathbf{5 a}$ for novel potent KSP inhibitors in terms of: (i) the linkage between the two aryl groups, (ii) the substituent on the right-hand phenyl group, (iii) the left-hand heterocycle, and (iv) the right-hand aromatic heterocycle (Figure 3).

A series of diaryl amine derivatives 5 and 11-14 were prepared by Buchwald-Hartwig $\mathrm{N}$-arylation using aryl bromides or triflates $\mathbf{9}$ and substituted anilines $\mathbf{1 0}$, except for the compounds (11j,l,n and 12c,k) indicated below (Scheme 1). ${ }^{21}$ Diphenylether derivative 17a was obtained by treatment of phenol derivative $\mathbf{1 5}$ with diaryliodonium tetrafluoroborate $\mathbf{1 6}$ in the presence of $\mathrm{KO}$ - $\mathrm{Bu} .^{23}$ Diphenylsulfide derivatives $\mathbf{2 0 a}, \mathbf{b}$ were prepared by the copper-catalyzed $\mathrm{C}-\mathrm{S}$ bond-forming reaction using aryl thiol $\mathbf{1 8}$ and $\mathrm{CF}_{3}$-substituted iodobenzenes 19a,b. ${ }^{24}$ Compounds 11j, 111, 11n and 12k were obtained by simple 
transformations including $\mathrm{BBr}_{3}$-mediated demethylation of $\mathbf{1 1} \mathbf{h}, \mathrm{Zn}$-mediated reduction of $\mathbf{1 1 k}$, saponification of $\mathbf{1 1} \mathbf{m}$, and thiocarbonylation of $\mathbf{5 a}$ using Lawesson's reagent, ${ }^{25}$ respectively. Compound 12c was prepared by treatment of $\mathbf{1 2 a}$ with $\mathrm{O}_{2}$ in the presence of $\operatorname{Pd}(\mathrm{OAc})_{2}$.

We initially investigated the type of heteroatom in the central part of diphenylamine 5a and the position of a substituent on the right-hand phenyl group (Table 3). Replacing the bridging $\mathrm{NH}$ group in compound 5a with oxygen $(\mathbf{1 7 a}, \mathbf{b}$ : ether) or sulfur $(\mathbf{2 0 a}, \mathbf{b}$ : thioether) resulted in a significant reduction or loss of KSP inhibitory activity. This indicates that the aniline $\mathrm{NH}$ group of 5a is an indispensable functional group as a hydrogen-bond donor, which is supported by our previous modeling study. ${ }^{16}$ Regarding the position of $\mathrm{CF}_{3}$ group on the right-hand phenyl ring of $\mathbf{5 a}, 4-\mathrm{CF}_{3}$ compound $\mathbf{5 b}$ was approximately 7 times less potent than $\mathbf{5 a}$ and no KSP inhibition of $2-\mathrm{CF}_{3}$ compound $\mathbf{5} \mathbf{c}$ was observed.

Next, the structure-activity relationship was examined by replacing 3-substituents on the right-hand phenyl group in 5a (Table 4). Among compounds 11a-d with or without a 3-alkyl substituent, the tert-butyl derivative $11 \mathbf{d}$ exhibited the most potent inhibitory activity $\left(\mathrm{IC}_{50}=\right.$ $0.16 \mu \mathrm{M})$. The structure-activity relationship of the simple alkyl group correlated with that of the carbazole-type KSP inhibitors, suggesting that carbazoles (1 and 2) and diphenylamines (5a and 11d) may occupy the same binding site of KSP. ${ }^{15,16}$ Substitution with 3,5-di-CF3 (11e), 3-phenyl (11f), 3-phenoxy (11g) and 3-methoxy (11h) groups were not effective. Introduction of a polar substituent such as 3-hydroxy (11j), 3-amino (11), 3-methoxycarbonyl (11 m), or 3-carboxylate (11n) also gave rise to inactive compounds. 3-Trifluoromethyloxy (11i) and 3-nitro (11k) derivatives showed moderate inhibitory activity. It is inferred from these data that the substituent at the 3-position on the right-hand phenyl part is buried in a relatively large hydrophobic pocket of KSP. The possible binding mode of $11 \mathbf{d}$ to the interface of the $\alpha 4$ and $\alpha 6$ helices of KSP is shown in Figure 5. The tert-butyl group of 11d was buried in the 
deep hydrophobic pocket formed by Tyr104, Gly296, Ile299, Thr300, Ile332, Tyr352, Ala353, and Ala356. Low desolvation energy of tert-butyl group compared with smaller alkyl groups may also contribute to the favorable binding of $11 \mathbf{d}$ to KSP.

In the left part of the molecule, the position of accessory amide group was crucial for the potency (Table 5). Compounds 12a-d with an amide group at the 3-position were less active or inactive, while the parent compound 5a with the 4-position amide group showed potent KSP inhibitory activity. A five-membered ring thiocarbamate $\mathbf{1 2 g}$ exhibited moderate inhibitory activity $\left(\mathrm{IC}_{50}=0.81 \mu \mathrm{M}\right)$ in contrast to the ineffectiveness in lactam derivative $\mathbf{1 2 e}$ and carbamate derivative 12f, suggesting that the introduction of a sulfur atom into the lactam ring had favorable effects on the bioactivity. The addition of a sulfur atom (12i) into the six-membered lactam of $\mathbf{5 a}$ also maintained potent KSP inhibitory activity $\left(\mathrm{IC}_{50}=0.051 \mu \mathrm{M}\right)$, whereas an oxygen atom $(\mathbf{1 2 h})$ decreased the inhibitory activity. The loss of activity in the $\mathrm{N}$-methylamide derivative $\mathbf{1 2} \mathbf{j}$ indicates that the lactam $\mathrm{NH}$ group at this position is essential for KSP inhibition. Compound $\mathbf{1 2 k}$, with a thioamide group, had slightly reduced potency $\left(\mathrm{IC}_{50}=0.19 \mu \mathrm{M}\right)$ compared with 5a. Compound 12l, with a seven-membered lactam, showed approximately equipotent $\mathrm{KSP}$ inhibitory activity $\left(\mathrm{IC}_{50}=0.050 \mu \mathrm{M}\right)$ to $\mathbf{5 a}$, suggesting that some flexibility of the lactam carbonyl placement is tolerated. Substitution with a fluorine group on the 5- or 6-position $(\mathbf{1 2} \mathbf{m}, \mathbf{n})$ resulted in a reduction in the inhibitory activity, suggesting that modification at these positions was inappropriate for favorable interactions with KSP.

\subsection{Analysis of aqueous solubility of potent KSP inhibitors and further optimization}

The thermodynamic solubility of potent diphenylamine derivatives $\mathbf{1 2 i} \mathbf{i} \mathbf{l}$ in aqueous media was next evaluated (Table 6). ${ }^{22}$ Diphenylamine $\mathbf{1 2} \mathbf{i}$ with a thiomorpholin-3-one structure was slightly less soluble $(1.70 \mathrm{mg} / \mathrm{mL}$ in $50 \% \mathrm{EtOH})$ than the parent compound $\mathbf{5 a}$. The longer 
retention time on a reversed-phase HPLC column (28.2 $\mathrm{min})$ of compound $\mathbf{1 2 \mathbf { i }}$ indicated that the introduction of a sulfur atom into the lactam ring of 5a resulted in the increased hydrophobicity, thereby lowering the solubility in aqueous media. Diphenylamine $\mathbf{1 2 l}$ with a seven-membered lactam ring was approximately four times more soluble $(7.39 \mathrm{mg} / \mathrm{mL}$ in $50 \% \mathrm{EtOH}$ ) than $\mathbf{5 a}$, although a high CLogP value and HPLC retention time indicated higher hydrophobicity. The lower melting point of compound $\mathbf{1 2 l}\left(140{ }^{\circ} \mathrm{C}\right)$ suggested that the weak crystal packing mainly contributed to the observed improvement in solubility. These results indicated that the seven-membered lactam ring on the left-hand phenyl group was a promising structural unit for the development of KSP inhibitors that have a favorable balance of bioactivity and aqueous solubility.

As such, we identified benzothiomorpholin-3-one $\mathbf{1 2} \mathbf{i}$ and benzoazepin-2-one $\mathbf{1 2} \mathbf{l}$ as potent KSP inhibitors using structure-activity relationship studies of fused heterocycles on the left-hand phenyl group. Compound $\mathbf{1 2 1}$ represents the lead compound for further structural refinements because of the improved solubility. Separately, examination of the right-hand phenyl group identified 6-pyridine derivative $\mathbf{6}$ with potent KSP inhibitory activity and improved aqueous solubility. ${ }^{16}$ On the basis of these promising components, two diaryl amine derivatives were then designed (Figure 4). Diaryl amine 13 was designed based on compound 12i with a thiomorpholin-3-one structure and compound 6 with a 6-pyridine ring. Diaryl amine $\mathbf{1 4}$ was similarly designed based on compounds $\mathbf{1 2 I}$ and $\mathbf{6}$.

Thiomorpholin-3-one $\mathbf{1 3}$ exhibited the most potent KSP inhibitory activity $\left(\mathrm{IC}_{50}=0.035\right.$ $\mu \mathrm{M}$ ) among the diaryl amine-type inhibitors that were examined in this study (Table 6). However, compound 13 was less soluble in $50 \% \mathrm{EtOH}(0.669 \mathrm{mg} / \mathrm{mL})$ and in phosphate buffer $(1.11 \mu \mathrm{g} / \mathrm{mL})$ than the parent compound $\mathbf{6}$. The high melting point of compound $\mathbf{1 3}$ $\left(217{ }^{\circ} \mathrm{C}\right)$ indicated that the tight crystal packing might cause this decrease in aqueous solubility. Benzoazepin-2-one $\mathbf{1 4}$ maintained highly potent $\mathrm{KSP}$ inhibitory activity $\left(\mathrm{IC}_{50}=\right.$ 
$0.050 \mu \mathrm{M})$ as seen for the parent compounds 5a, $\mathbf{6}$ and $\mathbf{1 2 l}$. Compound $\mathbf{1 4}$ exhibited greater solubility in $50 \%$ EtOH $(4.82 \mathrm{mg} / \mathrm{mL})$ and in phosphate buffer $(8.07 \mu \mathrm{g} / \mathrm{mL})$ than the corresponding compound 6. Of note, solubility of compound $\mathbf{1 4}$ in phosphate buffer was remarkably improved, as we expected, in comparison with compound $\mathbf{1 2 l}$ (less than $1 \mu \mathrm{g} / \mathrm{mL}$ ), although 14 was less soluble than $\mathbf{1 2 l}$ in $50 \% \mathrm{EtOH}$. Taken together, compound 14 was identified to be a novel KSP inhibitor with a favorable balance of potency and aqueous solubility.

Compounds 5a, 6, 12i,l, 13 and 14 were tested for their inhibitory effect on the proliferation of cancer cell lines: lung cancer cells A549, colorectal cancer cells HCT-116, and breast cancer cells MCF-7 (Table 7). Cells were treated with increasing concentrations of the compounds, and viabilities were measured by the 3-(4,5-dimethylthiazol-2-yl)-5-(3-carboxymethoxyphenyl)-2-(4-sulfophenyl)-2H-tetrazolium (MTS) assay. All the tested diaryl amine derivatives were shown to be effective against these cell lines. In particular, thiomorpholin-3-one derivative $\mathbf{1 3}$ with the highest KSP inhibitory activity was found to be the most potent against all the cell lines tested. ${ }^{26}$

\section{Conclusions}

We have performed structure-activity relationship studies for the development of novel KSP inhibitors using carbolines $\mathbf{3}$, carbazoles $\mathbf{4}$ and diphenylamine 5a as the lead compounds. Unfortunately, the nonplanar analogs 7 and $\mathbf{8}$ of planar carbolines $\mathbf{3}$ and carbazoles $\mathbf{4}$ decreased the potency for KSP inhibition. Optimization studies of diphenylamine 5a revealed that bridging $\mathrm{NH}$ group, 3- $\mathrm{CF}_{3}$ group on the right-hand phenyl group, and the lactam amide group at the 4-position on the left-hand phenyl group contributed to the potent KSP inhibitory activity. Further investigations provided novel KSP inhibitors 13 with the most potent inhibitory activity and $\mathbf{1 4}$ with the optimal balance of potency and aqueous solubility in this 
study.

\section{Experimental}

\subsection{Synthesis}

\subsubsection{General methods}

${ }^{1} \mathrm{H}$ NMR spectra were recorded using a JEOL AL-400 or a JEOL ECA-500 spectrometer. Chemical shifts are reported in $\delta$ (ppm) relative to $\mathrm{Me}_{4} \mathrm{Si}$ as an internal standard. ${ }^{13} \mathrm{C}$ NMR spectra were referenced to the residual DMSO signal. Exact mass (HRMS) spectra were recorded on a JMS-HX/HX 110A mass spectrometer. Melting points were measured by a hot stage melting point apparatus (uncorrected). For flash chromatography, Wakogel C-300E (Wako) or Chromatorex ${ }^{\circledR}$ NH was employed. For analytical HPLC, a Cosmosil 5C18-ARII column (4.6 x $250 \mathrm{~mm}$, Nacalai Tesque, Inc., Kyoto, Japan) was employed with a linear gradient of $\mathrm{CH}_{3} \mathrm{CN}$ containing $0.1 \%$ (v/v) TFA at a flow rate of $1 \mathrm{~mL} / \mathrm{min}$ on a Shimadzu LC-10ADvp (Shimadzu Corp., Ltd., Kyoto, Japan), and eluting products were detected by UV at $254 \mathrm{~nm}$. The purity of the compounds was determined by combustion analysis or HPLC analysis (>95\%).

\subsubsection{General procedure of $N$-arylation for preparation of diaryl amine compounds:} synthesis of 6-\{[3-(trifluoromethoxy)phenyl]amino\}-3,4-dihydroquinolin-2(1H)-one (11i)

Toluene $(4.5 \mathrm{~mL})$ was added to a flask containing 6-bromo-3,4-dihydroquinolin-2(1H)-one (300 mg, $1.33 \mathrm{mmol}), 3$-(trifluoromethoxy)aniline $(231 \mu \mathrm{L}, 1.73 \mathrm{mmol}), \mathrm{Pd}_{2}(\mathrm{dba})_{3}(15.2 \mathrm{mg}$, $0.02 \mathrm{mmol}), 2$-dicyclohexylphosphino-2',4',6'-triisopropylbiphenyl (31.6 mg, $0.07 \mathrm{mmol})$ and $\mathrm{NaOt}$-Bu (192 mg, $2.00 \mathrm{mmol})$ under an argon atmosphere. The mixture was stirred at $100{ }^{\circ} \mathrm{C}$ for $9 \mathrm{~h}$. After cooling, the reaction mixture was diluted with EtOAc, and filtered through a pad of Celite. The filtrate was concentrated in vacuo. Crude material was purified by flash 
chromatography with $n$-hexane/EtOAc (2:3) to afford the desired diaryl amine 11i $(292 \mathrm{mg}$, $68 \%$ yield): pale yellow solid; mp 160-162 ${ }^{\circ} \mathrm{C}$; IR (neat) $\mathrm{cm}^{-1}: 1667(\mathrm{C}=\mathrm{O}), 3219(\mathrm{NH}), 3315$ $(\mathrm{NH}) ;{ }^{1} \mathrm{H}$ NMR $\left(500 \mathrm{MHz}, \mathrm{DMSO}-d_{6}\right) \delta 2.43\left(\mathrm{t}, J=6.9 \mathrm{~Hz}, 2 \mathrm{H} ; \mathrm{CH}_{2}\right), 2.85(\mathrm{t}, J=6.9 \mathrm{~Hz}$, $\left.2 \mathrm{H} ; \mathrm{CH}_{2}\right), 6.63(\mathrm{~d}, J=8.0 \mathrm{~Hz}, 1 \mathrm{H} ; \mathrm{Ar}), 6.79$ (s, 1H; Ar), 6.81 (d, $J=8.0 \mathrm{~Hz}, 1 \mathrm{H}$; Ar), 6.91-6.96 (m, 3H; Ar), 7.25 (t, $J=8.0 \mathrm{~Hz}, 1 \mathrm{H} ; \mathrm{Ar}), 8.25(\mathrm{~s}, 1 \mathrm{H} ; \mathrm{NH}), 9.99(\mathrm{~s}, 1 \mathrm{H} ; \mathrm{NH}) ;{ }^{13} \mathrm{C}$ NMR (125 MHz, DMSO-d6) $\delta 25.0,30.4,106.3,109.6,113.1,115.8,118.7,119.5,120.1$ (q), 124.7, 130.7, 133.1, 136.1, 146.9, 149.4, 169.8; Anal. calcd for $\mathrm{C}_{16} \mathrm{H}_{13} \mathrm{~F}_{3} \mathrm{~N}_{2} \mathrm{O}_{2}$ : C, 59.63; $\mathrm{H}$, 4.07; N, 8.69. Found: C, 59.51; H, 4.12; N, 8.59.

\subsection{3. $N^{1}$-[3-(Trifluoromethyl)phenyl]benzene-1,3-diamine (8b)}

To a stirred solution of 3-nitro- $N$-[3-(trifluoromethyl)phenyl]aniline 8a (190 mg, 0.67 $\mathrm{mmol})$ and ammonium formate $(509 \mathrm{mg}, 8.07 \mathrm{mmol})$ in $\mathrm{EtOH}(2.2 \mathrm{~mL})$ at room temperature was added 10\% $\mathrm{Pd} / \mathrm{C}(35.8 \mathrm{mg}, 0.03 \mathrm{mmol})$. The mixture was heated under reflux for $2 \mathrm{~h}$. After cooling, the reaction mixture was diluted with EtOAc, and filtered through a pad of Celite. The filtrate was concentrated in vacuo. Crude material was purified by flash chromatography with $n$-hexane/EtOAc (3:1) to afford compound $\mathbf{8 b}$ (165 $\mathrm{mg}, 97 \%)$ : brown oil; IR (neat) cm ${ }^{-1}: 3035(\mathrm{NH}), 3377(\mathrm{NH}) ;{ }^{1} \mathrm{H}$ NMR (400 MHz, DMSO-d6) $\delta 4.96(\mathrm{~s}, 2 \mathrm{H}$; $\left.\mathrm{NH}_{2}\right), 6.19(\mathrm{~d}, J=8.0 \mathrm{~Hz}, 1 \mathrm{H} ; \mathrm{Ar}), 6.28(\mathrm{~d}, J=8.0 \mathrm{~Hz}, 1 \mathrm{H} ; \mathrm{Ar}), 6.37$ (s, 1H; Ar), 6.92 (t, $J=$ $8.0 \mathrm{~Hz}, 1 \mathrm{H}$; Ar), 7.01 (d, $J=8.0 \mathrm{~Hz}, 1 \mathrm{H}$; Ar), 7.22 (s, 1H; Ar), 7.25 (d, J=8.2 Hz, 1H; Ar), $7.37(\mathrm{t}, J=8.0 \mathrm{~Hz}, 1 \mathrm{H} ; \mathrm{Ar}), 8.13(\mathrm{~s}, 1 \mathrm{H} ; \mathrm{NH}) ;{ }^{13} \mathrm{C} \mathrm{NMR}\left(125 \mathrm{MHz}, \mathrm{DMSO}-d_{6}\right) \delta 104.0,106.5$, $107.8,111.3,114.3,118.8,124.3$ (q), 129.6, 129.8 (q), 130.0, 142.5, 145.2, 149.7; HRMS (FAB): $m / z$ calcd for $\mathrm{C}_{13} \mathrm{H}_{11} \mathrm{~F}_{3} \mathrm{~N}_{2}\left(\mathrm{M}^{+}\right)$252.0874; found: 252.0874 .

\subsubsection{1-(3-\{[3-(Trifluoromethyl)phenyl]amino\}phenyl)urea (8c)}

To a stirred solution of $N^{1}$-[3-(trifluoromethyl)phenyl]benzene-1,3-diamine $\mathbf{8 b}(80.0 \mathrm{mg}$, 
$0.32 \mathrm{mmol})$ in $\mathrm{AcOH}(4.0 \mathrm{~mL})$ was added $\mathrm{KOCN}(77.2 \mathrm{mg}, 0.95 \mathrm{mmol})$ and water $(80.0 \mu \mathrm{L})$. The reaction mixture was stirred at room temperature for $18 \mathrm{~h}$, then evaporated to dryness under vacuum. Crude material was purified by flash chromatography with amino silica gel with $\mathrm{CHCl}_{3} / \mathrm{MeOH}$ (20:1 to $\left.10: 1\right)$ to afford compound $\mathbf{8 c}$ (31.9 mg, 34\% yield): yellow oil; IR (neat) $\mathrm{cm}^{-1}: 1661(\mathrm{C}=\mathrm{O}), 3225(\mathrm{NH}), 3351(\mathrm{NH}) ;{ }^{1} \mathrm{H}$ NMR $\left(500 \mathrm{MHz}, \mathrm{DMSO}-d_{6}\right) \delta 5.82(\mathrm{br}$, 2H; $\left.\mathrm{NH}_{2}\right), 6.66(\mathrm{~d}, J=8.0 \mathrm{~Hz}, 1 \mathrm{H} ; \mathrm{Ar}), 6.84(\mathrm{~d}, J=8.0 \mathrm{~Hz}, 1 \mathrm{H} ; \mathrm{Ar}), 7.06(\mathrm{~d}, J=8.0 \mathrm{~Hz}, 1 \mathrm{H}$; Ar), 7.12 (t, $J=8.0 \mathrm{~Hz}, 1 \mathrm{H}$; Ar), $7.28(\mathrm{~s}, 1 \mathrm{H} ; \mathrm{Ar}), 7.30$ (d, J=8.0 Hz, 1H; Ar), 7.41 (s, 1H; Ar), $7.42(\mathrm{t}, J=8.0 \mathrm{~Hz}, 1 \mathrm{H} ; \mathrm{Ar}), 8.50(\mathrm{br}, 2 \mathrm{H} ; \mathrm{NH}) ;{ }^{13} \mathrm{C} \mathrm{NMR}\left(125 \mathrm{MHz}, \mathrm{DMSO}-d_{6}\right) \delta 107.4$, $110.7,110.9,111.5,114.8,118.9,124.2$ (q), 129.3, 129.8 (q), 130.1, 141.5, 142.2, 144.6, 155.8; HRMS (FAB): $m / z$ calcd for $\mathrm{C}_{14} \mathrm{H}_{12} \mathrm{~F}_{3} \mathrm{~N}_{3} \mathrm{O}\left(\mathrm{M}^{+}\right)$295.0932; found: 295.0926 .

\subsubsection{6-[(3-Hydroxyphenyl)amino]-3,4-dihydroquinolin-2(1H)-one (11j)}

A suspension of 6-[(3-methoxyphenyl)amino]-3,4-dihydroquinolin-2(1H)-one $11 \mathbf{h}(500 \mathrm{mg}$, $1.86 \mathrm{mmol})$ in dry $\mathrm{CH}_{2} \mathrm{Cl}_{2}(5 \mathrm{~mL})$ was cooled to $-78{ }^{\circ} \mathrm{C}$ and then $\mathrm{BBr} 3(7.45 \mathrm{~mL}$ of $1 \mathrm{M}$ solution in $\mathrm{CH}_{2} \mathrm{Cl}_{2}, 7.45 \mathrm{mmol}$ ) was added. After the mixture was stirred for $30 \mathrm{~min}$ at $-78{ }^{\circ} \mathrm{C}$, the stirring was continued for additional $18 \mathrm{~h}$ at room temperature. The reaction was quenched by addition of water $(12 \mathrm{~mL})$, and $\mathrm{CH}_{2} \mathrm{Cl}_{2}$ was removed under reduced pressure. The aqueous solution was neutralized by addition of aqueous $\mathrm{NaOH}$, and then extracted three times with EtOAc. The organic layer was washed with brine, and dried over $\mathrm{Na}_{2} \mathrm{SO}_{4}$. The organic solvent was removed under reduced pressure and the crude residue was purified by flash chromatography with $n$-hexane/EtOAc (1:3) to afford compound $\mathbf{1 1} \mathbf{j}$ (232 $\mathrm{mg}, 49 \%$ yield): brown needle crystal; $\mathrm{mp} 213-214{ }^{\circ} \mathrm{C}$; IR (neat) $\mathrm{cm}^{-1}$ : $1651(\mathrm{C}=\mathrm{O}), 3222(\mathrm{NH}), 3321(\mathrm{NH})$; ${ }^{1} \mathrm{H}$ NMR (500 MHz, DMSO-d6) $\delta 2.41\left(\mathrm{t}, J=7.4 \mathrm{~Hz}, 2 \mathrm{H} ; \mathrm{CH}_{2}\right), 2.81\left(\mathrm{t}, J=7.4 \mathrm{~Hz}, 2 \mathrm{H} ; \mathrm{CH}_{2}\right)$, $6.15(\mathrm{~d}, J=8.0 \mathrm{~Hz}, 1 \mathrm{H} ; \mathrm{Ar}), 6.38(\mathrm{~d}, J=8.0 \mathrm{~Hz}, 1 \mathrm{H} ; \mathrm{Ar}), 6.39$ (s, 1H; Ar), 6.74 (d, $J=8.0 \mathrm{~Hz}$, 1H; Ar), 6.85 (d, $J=8.0 \mathrm{~Hz}, 1 \mathrm{H} ; \mathrm{Ar}), 6.89$ (s, 1H; Ar), 6.94 (t, $J=8.0 \mathrm{~Hz}, 1 \mathrm{H} ; \mathrm{Ar}), 7.77$ (s, 
1H; NH), 9.07 (s, 1H; OH), 9.89 (s, $1 \mathrm{H} ; \mathrm{NH}) ;{ }^{13} \mathrm{C}$ NMR (125 MHz, DMSO- $\left.d_{6}\right) \delta 25.1,30.5$, 102.2, 106.0, 106.6, 115.6, 117.4, 118.2, 124.4, 129.7, 131.7, 137.7, 145.8, 158.1, 169.7; Anal. calcd for $\mathrm{C}_{15} \mathrm{H}_{14} \mathrm{~N}_{2} \mathrm{O}_{2}:$ C, $70.85 ; \mathrm{H}, 5.55 ; \mathrm{N}, 11.02$. Found: $\mathrm{C}, 71.11 ; \mathrm{H}, 5.59 ; \mathrm{N}, 10.89$.

\subsubsection{6-[(3-Aminophenyl)amino]-3,4-dihydroquinolin-2(1H)-one (11I)}

To a stirred solution of 6-[(3-nitrophenyl)amino]-3,4-dihydroquinolin-2(1H)-one 11k (62.0 $\mathrm{mg}, 0.22 \mathrm{mmol})$ in $\mathrm{AcOH}(2.2 \mathrm{~mL})$ at room temperature was added zinc powder $(102 \mathrm{mg}$, $1.56 \mathrm{mmol}$ ) portionwise. After being stirred at room temperature for $1 \mathrm{~h}$, the reaction mixture was filtered through a pad of Celite and concentrated under vacuum. The residue was diluted with EtOAc, and the whole was washed with saturated $\mathrm{NaHCO}_{3}$, brine, and dried over $\mathrm{Na}_{2} \mathrm{SO}_{4}$. The organic solvent was removed under reduced pressure and the crude residue was purified by flash chromatography with $n$-hexane/EtOAc (1:8) to afford compound 111 (41.6 mg, 75\% yield): pale yellow solid; $\mathrm{mp} 196-198{ }^{\circ} \mathrm{C}$; IR (neat) $\mathrm{cm}^{-1}: 1662(\mathrm{C}=\mathrm{O}), 3221(\mathrm{NH})$, $3344(\mathrm{NH}) ;{ }^{1} \mathrm{H}$ NMR $\left(500 \mathrm{MHz}, \mathrm{DMSO}-d_{6}\right) \delta 2.40\left(\mathrm{t}, J=7.4 \mathrm{~Hz}, 2 \mathrm{H} ; \mathrm{CH}_{2}\right), 2.80(\mathrm{t}, J=7.4$ $\mathrm{Hz}, 2 \mathrm{H} ; \mathrm{CH}_{2}$ ), 4.93 (br, 2H; $\left.\mathrm{NH}_{2}\right), 6.00$ (d, $\left.J=8.0 \mathrm{~Hz}, 1 \mathrm{H} ; \mathrm{Ar}\right), 6.15$ (d, $\left.J=8.0 \mathrm{~Hz}, 1 \mathrm{H} ; \mathrm{Ar}\right)$, 6.24 (s, 1H; Ar), 6.72 (d, $J=8.0 \mathrm{~Hz}, 1 \mathrm{H} ; \mathrm{Ar}), 6.80$ (d, $J=8.0 \mathrm{~Hz}, 1 \mathrm{H} ; \operatorname{Ar}), 6.83$ (d, $J=8.0 \mathrm{~Hz}$, 1H; Ar), 6.86 (s, 1H; Ar), $7.58(\mathrm{~s}, 1 \mathrm{H} ; \mathrm{NH}), 9.87(\mathrm{~s}, 1 \mathrm{H} ; \mathrm{NH}) ;{ }^{13} \mathrm{C} \mathrm{NMR}(125 \mathrm{MHz}$, DMSO- $d 6) \delta 25.2,30.5,101.4,104.5,105.7,115.5,116.9,117.7,124.3,129.3,131.2,138.3$, 145.0, 149.2, 169.6; HRMS (FAB): calcd for $\mathrm{C}_{15} \mathrm{H}_{15} \mathrm{~N}_{3} \mathrm{O}\left(\mathrm{M}^{+}\right)$253.1215; found: 253.1213 .

\subsubsection{3-[(2-Oxo-1,2,3,4-tetrahydroquinolin-6-yl)amino]benzoic acid (11n)}

To a solution of methyl 3-[(2-oxo-1,2,3,4-tetrahydroquinolin-6-yl)amino]benzoate $\mathbf{1 1 m}$ (400 mg, $1.35 \mathrm{mmol})$ in $5.2 \mathrm{~mL}$ of $\mathrm{MeOH} / \mathrm{H}_{2} \mathrm{O}(3: 1 \mathrm{v} / \mathrm{v})$ was added $\mathrm{LiOH} \cdot \mathrm{H}_{2} \mathrm{O}(170 \mathrm{mg}, 4.05$ mmol) at $0{ }^{\circ} \mathrm{C}$, then the solution was warmed to $50{ }^{\circ} \mathrm{C}$. After $1 \mathrm{~h}$, the reaction mixture was acidified to below pH 2 using $1 \mathrm{M} \mathrm{HCl}$, then EtOAc and brine were added to the mixture. The 
organic extracts were washed with brine and dried over $\mathrm{Na}_{2} \mathrm{SO}_{4}$. The organic solvent was removed under reduced pressure to afford compound 11n (366 mg, 96\% yield): white solid; mp 259-261 ${ }^{\circ} \mathrm{C}$; IR (neat) $\mathrm{cm}^{-1}: 1656(\mathrm{C}=\mathrm{O}), 1684(\mathrm{C}=\mathrm{O}), 3203(\mathrm{NH}), 3326(\mathrm{NH}) ;{ }^{1} \mathrm{H}$ NMR (500 MHz, DMSO-d6) $\delta 2.43\left(\mathrm{t}, J=7.4 \mathrm{~Hz}, 2 \mathrm{H} ; \mathrm{CH}_{2}\right), 2.85\left(\mathrm{t}, J=7.4 \mathrm{~Hz}, 2 \mathrm{H} ; \mathrm{CH}_{2}\right), 6.81(\mathrm{~d}$, $J=8.0 \mathrm{~Hz}, 1 \mathrm{H} ; \mathrm{Ar}), 6.93(\mathrm{~d}, J=8.0 \mathrm{~Hz}, 1 \mathrm{H} ; \mathrm{Ar}), 6.94(\mathrm{~s}, 1 \mathrm{H} ; \mathrm{Ar}), 7.17$ (d, $J=8.0 \mathrm{~Hz}, 1 \mathrm{H} ; \mathrm{Ar})$, 7.27-7.31 (m, 2H; Ar), 7.53 (s, 1H; Ar), 8.12 (s, 1H; NH), 9.98 (s, 1H; NH), 12.78 (br, 1H; $\left.\mathrm{CO}_{2} \mathrm{H}\right) ;{ }^{13} \mathrm{C}$ NMR (125 MHz, DMSO- $\left.d_{6}\right) \delta 25.1,30.4,115.5,115.8,118.1,118.9,119.0,119.2$, 124.6, 129.3, 131.7, 132.6, 136.9, 145.2, 167.6, 169.8; HRMS (FAB): $\mathrm{m} / \mathrm{z}$ calcd for $\mathrm{C}_{16} \mathrm{H}_{14} \mathrm{~N}_{2} \mathrm{O}_{3}\left(\mathrm{M}^{+}\right)$282.1004; found: 282.1011.

\subsubsection{7-\{[3-(Trifluoromethyl)phenyl]amino\}quinolin-2(1H)-one (12c)}

$\mathrm{AcOH} \quad\left(\begin{array}{ll}1.0 & \mathrm{~mL}\end{array}\right)$ was added to a flask containing 7-\{[3-(trifluoromethyl)phenyl]amino) $\}$-3,4-dihydroquinolin-2(1H)-one 12a $(80.0 \mathrm{mg}, 0.26$ mmol $)$ and $\mathrm{Pd}(\mathrm{OAc}) 2(22.4 \mathrm{mg}, 0.10 \mathrm{mmol})$ and an oxygen balloon was connected to the reaction vessel. After stirring for $2 \mathrm{~h}$ at $115{ }^{\circ} \mathrm{C}$, the reaction mixture was cooled to room temperature and concentrated in vacuo. The residue was purified by flash chromatography with $n$-hexane/EtOAc (1:3 to $1: 5)$ to afford $12 \mathrm{c}(34.1 \mathrm{mg}, 43 \%$ yield): white solid; mp 177-179 ${ }^{\circ} \mathrm{C}$; IR (neat) $\mathrm{cm}^{-1}: 1655(\mathrm{C}=\mathrm{O}), 3452(\mathrm{NH}) ;{ }^{1} \mathrm{H}$ NMR $(500 \mathrm{MHz}, \mathrm{DMSO}-d 6) \delta 6.24$ (d, $J=9.2 \mathrm{~Hz}, 1 \mathrm{H} ; \mathrm{C}=\mathrm{CH}), 6.88(\mathrm{dd}, J=8.0,2.3 \mathrm{~Hz}, 1 \mathrm{H} ; \mathrm{Ar}), 7.06(\mathrm{~d}, J=2.3 \mathrm{~Hz}, 1 \mathrm{H}$; Ar), $7.23(\mathrm{~d}, J=8.0 \mathrm{~Hz}, 1 \mathrm{H} ; \mathrm{Ar}), 7.41(\mathrm{~s}, 1 \mathrm{H} ; \mathrm{Ar}), 7.45(\mathrm{~d}, J=8.0 \mathrm{~Hz}, 1 \mathrm{H} ; \mathrm{Ar}), 7.50-7.53(\mathrm{~m}, 2 \mathrm{H}$; $\operatorname{Ar}), 7.75(\mathrm{~d}, J=9.2 \mathrm{~Hz}, 1 \mathrm{H} ; \mathrm{C}=\mathrm{CH}), 8.99(\mathrm{~s}, 1 \mathrm{H} ; \mathrm{NH}), 11.53(\mathrm{~s}, 1 \mathrm{H} ; \mathrm{NH}) ;{ }^{13} \mathrm{C} \mathrm{NMR}(125$ MHz, DMSO- $\left.d_{6}\right) \delta 99.7,112.3,113.1,113.5,116.7,117.7,121.0,124.1$ (q), 129.0, 130.0 (q), 130.4, 139.8, 140.5, 142.9, 144.5, 162.2; HRMS (FAB): $m / z$ calcd for $\mathrm{C}_{16} \mathrm{H}_{11} \mathrm{~F}_{3} \mathrm{~N}_{2} \mathrm{O}[\mathrm{M}+\mathrm{H}]^{+}$ 305.0902; found: 305.0905 . 


\subsubsection{6-\{[3-(Trifluoromethyl)phenyl]amino $\}-3,4-d i h y d r o q u i n o l i n e-2(1 H)$-thione (12k)}

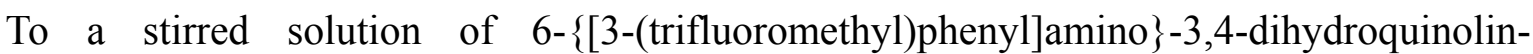
2(1H)-one $5 \mathbf{a}(50.0 \mathrm{mg}, 0.16 \mathrm{mmol})$ in toluene $(1.0 \mathrm{~mL})$ was added Lawesson's reagent $(33.0$ $\mathrm{mg}, 0.08 \mathrm{mmol}$ ) under an argon atmosphere. After stirring for $30 \mathrm{~min}$ at $110{ }^{\circ} \mathrm{C}$, the reaction mixture was cooled to room temperature and concentrated in vacuo. The residue was purified by flash chromatography with $n$-hexane/EtOAc (3:1) to afford 12k (51.4 mg, 100\% yield): yellow solid; mp 195-196 ${ }^{\circ} \mathrm{C}$; IR (neat) $\mathrm{cm}^{-1}$ : $1499(\mathrm{C}=\mathrm{S}), 3361(\mathrm{NH}) ;{ }^{1} \mathrm{H}$ NMR $(500 \mathrm{MHz}$, DMSO-d $d_{6} \delta 2.77\left(\mathrm{t}, J=8.0 \mathrm{~Hz}, 2 \mathrm{H} ; \mathrm{CH}_{2}\right), 2.90\left(\mathrm{t}, J=8.0 \mathrm{~Hz}, 2 \mathrm{H} ; \mathrm{CH}_{2}\right), 6.97(\mathrm{~s}, 1 \mathrm{H} ; \mathrm{Ar})$, $6.98(\mathrm{~d}, J=8.0 \mathrm{~Hz}, 1 \mathrm{H} ; \mathrm{Ar}), 7.04(\mathrm{~d}, J=8.0 \mathrm{~Hz}, 1 \mathrm{H} ; \mathrm{Ar}), 7.06$ (d, $J=8.0 \mathrm{~Hz}, 1 \mathrm{H} ; \mathrm{Ar}), 7.20$ (s, 1H; Ar), 7.27 (d, $J=8.0 \mathrm{~Hz}, 1 \mathrm{H} ; \mathrm{Ar}), 7.41(\mathrm{~d}, J=8.0 \mathrm{~Hz}, 1 \mathrm{H} ; \mathrm{Ar}), 8.49$ (s, 1H; NH), 12.15 (s, $1 \mathrm{H} ; \mathrm{NH}) ;{ }^{13} \mathrm{C}$ NMR $\left(125 \mathrm{MHz}, \mathrm{DMSO}-d_{6}\right) \delta 24.0,38.9,111.4,114.9,117.0,117.3,118.3$, 118.5, 124.3 (q), 126.6, 130.0 (q), 130.3, 131.3, 138.3, 144.9, 197.3; HRMS (FAB): $m / z$ calcd for $\mathrm{C}_{16} \mathrm{H}_{13} \mathrm{~F}_{3} \mathrm{~N}_{2} \mathrm{~S}\left(\mathrm{M}^{+}\right)$322.0752; found: 322.0758.

\subsubsection{7-\{[4-(Trifluoromethyl)pyridin-2-yl]amino $\}$-2H-benzo $[b][1,4]$ thiazin-3(4H)-one} (13)

Following the general procedure for 11i, compound 13 (48.5 $\mathrm{mg}, 12 \%$ yield) was synthesized from 7-bromo- $2 H$-benzo $[b][1,4]$ thiazin-3(4H)-one and 2-amino-4(trifluoromethyl)pyridine: white solid; mp 217-218 ${ }^{\circ} \mathrm{C}$; IR (neat) $\mathrm{cm}^{-1}: 1688(\mathrm{C}=\mathrm{O}), 3194$ (NH); ${ }^{1} \mathrm{H}$ NMR (500 MHz, DMSO-d6) $\delta 3.45\left(\mathrm{~s}, 2 \mathrm{H} ; \mathrm{CH}_{2}\right), 6.92(\mathrm{~d}, J=8.6 \mathrm{~Hz}, 1 \mathrm{H} ; \mathrm{Ar}), 6.99$ $(\mathrm{d}, J=5.2 \mathrm{~Hz}, 1 \mathrm{H} ; \mathrm{Ar}), 7.03(\mathrm{~s}, 1 \mathrm{H} ; \mathrm{Ar}), 7.33(\mathrm{dd}, J=8.6,1.7 \mathrm{~Hz}, 1 \mathrm{H} ; \mathrm{Ar}), 7.81(\mathrm{~d}, J=1.7 \mathrm{~Hz}$, 1H; Ar), 8.37 (d, $J=5.2 \mathrm{~Hz}, 1 \mathrm{H}$; Ar), $9.43(\mathrm{~s}, 1 \mathrm{H} ; \mathrm{NH}), 10.44(\mathrm{~s}, 1 \mathrm{H} ; \mathrm{NH}) ;{ }^{13} \mathrm{C}$ NMR $(125$ MHz, DMSO-d6) $\delta 29.1,106.2,108.6,117.1,117.5,117.7,119.3,123.0$ (q), 131.7, 135.9, 137.6 (q), 149.3, 156.1, 164.8; HRMS (FAB): $m / z$ calcd for $\mathrm{C}_{14} \mathrm{H}_{10} \mathrm{~F}_{3} \mathrm{~N}_{3} \mathrm{OS}\left(\mathrm{M}^{+}\right)$325.0497; found: 325.0497 . 


\subsubsection{7-\{[4-(Trifluoromethyl)pyridin-2-yl]amino\}-1,3,4,5-tetrahydro-2H-benzo[b]aze- pin-2-one (14)}

Following the general procedure for 11i, compound $\mathbf{1 4}(16.7 \mathrm{mg}, 18 \%$ yield) was synthesized from 7-bromo-1,3,4,5-tetrahydro-2H-benzo[b]azepin-2-one and 2-amino-4-(trifluoromethyl)pyridine: pale yellow solid; mp $185-187^{\circ} \mathrm{C}$; IR (neat) $\mathrm{cm}^{-1}$ : 1688 $(\mathrm{C}=\mathrm{O}), 2936(\mathrm{NH}) ;{ }^{1} \mathrm{H}$ NMR $\left(500 \mathrm{MHz}, \mathrm{DMSO}-d_{6}\right) \delta 2.09-2.16\left(\mathrm{~m}, 4 \mathrm{H} ; \mathrm{CH}_{2} \times 2\right), 2.67(\mathrm{t}, J$ $\left.=6.9 \mathrm{~Hz}, 2 \mathrm{H} ; \mathrm{CH}_{2}\right), 6.92(\mathrm{~d}, J=8.0 \mathrm{~Hz}, 1 \mathrm{H} ; \mathrm{Ar}), 6.98(\mathrm{~d}, J=5.2 \mathrm{~Hz}, 1 \mathrm{H} ; \mathrm{Ar}), 7.07(\mathrm{~s}, 1 \mathrm{H} ; \mathrm{Ar})$, $7.53(\mathrm{~d}, J=8.0 \mathrm{~Hz}, 1 \mathrm{H} ; \mathrm{Ar}), 7.55$ (s, 1H; Ar), 8.37 (d, $J=5.2 \mathrm{~Hz}, 1 \mathrm{H} ; \mathrm{Ar}), 9.36$ (s, 1H; NH), 9.42 (s, 1H; NH); ${ }^{13} \mathrm{C}$ NMR (125 MHz, DMSO-d6) $\delta 27.8,30.1,32.7,106.0,108.4,117.4$, 119.6, 121.9, 122.0, 123.0 (q), 132.7, 134.1, 137.4, 137.5 (q), 149.3, 156.3, 173.1; HRMS (FAB): $m / z$ calcd for $\mathrm{C}_{16} \mathrm{H}_{14} \mathrm{~F}_{3} \mathrm{~N}_{3} \mathrm{O}\left(\mathrm{M}^{+}\right) 321.1089$; found: 321.1092 .

\subsubsection{6-[3-(Trifluoromethyl)phenoxy]-3,4-dihydroquinolin-2(1H)-one (17a)}

To a suspension of $\mathrm{KO} t$ - $\mathrm{Bu}(60.5 \mathrm{mg}, 0.54 \mathrm{mmol})$ in DMF $(2.1 \mathrm{~mL})$ was added 6-hydroxy-3,4-dihydroquinolin-2(1H)-one $15(80.0 \mathrm{mg}, 0.49 \mathrm{mmol})$ at $0{ }^{\circ} \mathrm{C}$ and the reaction mixture was stirred at this temperature for $15 \mathrm{~min}$. Bis(3-trifluoromethylphenyl)iodonium tetrafluoroborate $16(259 \mathrm{mg}, 0.51 \mathrm{mmol})$ was added in one portion and the reaction mixture was stirred at $40{ }^{\circ} \mathrm{C}$ for $1 \mathrm{~h}$, then quenched with $\mathrm{H}_{2} \mathrm{O}$ at $0{ }^{\circ} \mathrm{C}$ and extracted into $\mathrm{CHCl}_{3}$. The organic layer was washed with brine, and dried over $\mathrm{Na}_{2} \mathrm{SO}_{4}$. The organic solvent was removed under reduced pressure and the crude residue was purified by flash chromatography with $n$-hexane/EtOAc (1:1) to afford compound 17a (39.9 mg, 27\% yield): white solid; mp 158-159 ${ }^{\circ} \mathrm{C}$; IR (neat) $\mathrm{cm}^{-1}: 1681(\mathrm{C}=\mathrm{O}), 3203(\mathrm{NH}) ;{ }^{1} \mathrm{H}$ NMR $(500 \mathrm{MHz}$, DMSO-d6) $\delta 2.44$ (t, $\left.J=7.4 \mathrm{~Hz}, 2 \mathrm{H} ; \mathrm{CH}_{2}\right), 2.87$ (t, $J=7.4 \mathrm{~Hz}, 2 \mathrm{H} ; \mathrm{CH}_{2}$ ), 6.91 (s, 2H; Ar), 6.99 (s, 1H; Ar), 7.20-7.23 (m, 2H; Ar), 7.42 (d, $J=8.0 \mathrm{~Hz}, 1 \mathrm{H}$; Ar), 7.58 (t, $J=8.0 \mathrm{~Hz}, 1 \mathrm{H} ;$ Ar), 10.12 (s, 1H; 
$\mathrm{NH}) ;{ }^{13} \mathrm{C}$ NMR (125 MHz, DMSO-d6) $\delta 24.7,30.0,113.6,116.3,118.7,119.1,119.5,121.0$, 123.7 (q), 125.7, 130.6 (q), 131.2, 135.3, 149.6, 158.4, 169.9; HRMS (FAB): $m / z$ calcd for $\mathrm{C}_{16} \mathrm{H}_{12} \mathrm{~F}_{3} \mathrm{NO}_{2}\left(\mathrm{M}^{+}\right)$307.0820; found: 307.0826 .

\subsubsection{6-\{[3-(Trifluoromethyl)phenyl]thio\}-3,4-dihydroquinolin-2(1H)-one (20a)}

2-Propanol (1.0 $\mathrm{mL})$ was added to a flask containing 6-mercapto-3,4-dihydroquinolin-2(1H)-one $\quad 18 \quad(50.0 \quad \mathrm{mg}, \quad 0.28 \quad \mathrm{mmol})$, 3-trifluoromethyliodobenzene 19a (40.4 $\mu \mathrm{L}, 0.28 \mathrm{mmol}), \mathrm{CuI}(32.0 \mathrm{mg}, 0.17 \mathrm{mmol})$, ethylene glycol $(31.2 \mu \mathrm{L}, 0.56 \mathrm{mmol})$ and $\mathrm{K}_{2} \mathrm{CO}_{3}(96.7 \mathrm{mg}, 0.70 \mathrm{mmol})$ under an argon atmosphere. The mixture was stirred at $80{ }^{\circ} \mathrm{C}$ for $13 \mathrm{~h}$. After cooling, the reaction mixture was diluted with EtOAc, and filtered through a pad of Celite. The filtrate was concentrated in vacuo. Crude material was purified by flash chromatography with $n$-hexane/EtOAc $(3: 2)$ to afford compound 20a $\left(6.2 \mathrm{mg}, 7 \%\right.$ yield): white solid; mp 102-104 ${ }^{\circ} \mathrm{C}$; IR (neat) $\mathrm{cm}^{-1}: 1676(\mathrm{C}=\mathrm{O})$, $3387(\mathrm{NH}) ;{ }^{1} \mathrm{H}$ NMR $\left(500 \mathrm{MHz}, \mathrm{DMSO}-d_{6}\right) \delta 2.53\left(\mathrm{t}, J=7.4 \mathrm{~Hz}, 2 \mathrm{H} ; \mathrm{CH}_{2}\right), 2.96(\mathrm{t}, J=7.4$ $\left.\mathrm{Hz}, 2 \mathrm{H} ; \mathrm{CH}_{2}\right), 7.00$ (d, $\left.J=8.0 \mathrm{~Hz}, 1 \mathrm{H} ; \mathrm{Ar}\right), 7.40$ (d, $\left.J=8.0 \mathrm{~Hz}, 1 \mathrm{H} ; \mathrm{Ar}\right), 7.42-7.45$ (m, 2H; Ar), $7.49(\mathrm{~s}, 1 \mathrm{H} ; \mathrm{Ar}), 7.58-7.59(\mathrm{~m}, 2 \mathrm{H} ; \mathrm{Ar}), 10.34(\mathrm{~s}, 1 \mathrm{H} ; \mathrm{NH}) ;{ }^{13} \mathrm{C} \mathrm{NMR}(125 \mathrm{MHz}$ DMSO- $\left.d_{6}\right) \delta 24.4,30.0,116.4,122.4,122.6,123.0,123.7$ (q), 125.4, 129.9 (q), 130.3, 131.0, 133.5, 133.7, 139.5, 140.1, 170.1; HRMS (FAB): $m / z$ calcd for $\mathrm{C}_{16} \mathrm{H}_{12} \mathrm{~F}_{3} \mathrm{NOS}\left(\mathrm{M}^{+}\right)$323.0592; found: 323.0591

\subsection{KSP ATPase assay}

The microtubules-stimulated KSP ATPase reaction was performed in a reaction buffer [20 mM PIPES-KOH (pH 6.8), $25 \mathrm{mM} \mathrm{KCl,} 2 \mathrm{mM} \mathrm{MgCl} 2,1 \mathrm{mM}$ EGTA-KOH (pH 8.0)] containing $38 \mathrm{nM}$ of the bacteria-expressed KSP motor domain (1-369) fused to histidine-tag at the carboxyl-terminus and $350 \mathrm{nM}$ microtubules in 96-well half-area plates (Corning). Each 
chemical compound in DMSO at different concentrations was diluted 12.5 -fold with the chemical dilution buffer [10 mM Tris-OAc (pH7.4), 0.04\% (v/v) NP-40]. After pre-incubation of $9.7 \mu \mathrm{L}$ of the enzyme solution with $3.8 \mu \mathrm{L}$ of each chemical solution at $25^{\circ} \mathrm{C}$ for $30 \mathrm{~min}$, the ATPase reaction was initiated by the addition of $1.5 \mu \mathrm{L}$ of $0.3 \mathrm{mM}$ ATP solution, and followed by incubation at $25{ }^{\circ} \mathrm{C}$ for further $15 \mathrm{~min}$. The reaction was terminated by the addition of $15 \mu \mathrm{L}$ of the Kinase-Glo Plus reagent (Promega). The ATP consumption in each reaction was measured as the luciferase-derived luminescence by ARVO Light (PerkinElmer). At least three experiments were performed per condition and the averages and standard deviations of inhibition rates in each condition were evaluated to determine IC $_{50}$ values using the GraphPad Prism software.

\subsection{Growth inhibition assay}

A549, HCT-116 and MCF-7 cells were cultured in Dulbecco's modified Eagle's medium (DMEM, Sigma), McCoy’s 5A medium (GIBCO) and Eagle's minimal essential medium (EMEM, Wako), respectively, supplemented with $10 \%(\mathrm{v} / \mathrm{v})$ fetal bovine serum at $37{ }^{\circ} \mathrm{C}$ in a $5 \% \mathrm{CO}_{2}$-incubator. Growth inhibition assays using these cells were performed in 96-well plates (BD Falcon). A549, HCT-116 and MCF-7 cells were seeded at 500, 5000 and 5000 cells/well in $50 \mu \mathrm{L}$ of culture media, respectively, and were cultured for $6 \mathrm{~h}$. Chemical compounds in DMSO were diluted 250-fold with the culture medium in advance. Following the addition of $40 \mu \mathrm{L}$ of the fresh culture medium to the cell cultures, $30 \mu \mathrm{L}$ of the chemical diluents were also added. The final volume of DMSO in the medium was equal to $0.1 \%(\mathrm{v} / \mathrm{v})$. The cells under chemical treatment were incubated for further $72 \mathrm{~h}$. The wells in the plates were washed twice with the cultured medium without phenol-red. After $1 \mathrm{~h}$ incubation with $100 \mu \mathrm{L}$ of the medium, the cell culture in each well was supplemented with $20 \mu \mathrm{L}$ of the MTS reagent (Promega), followed by incubation for additional $40 \mathrm{~min}$. Absorbance at $490 \mathrm{~nm}$ of 
each well was measured using a Wallac 1420 ARVO SX multilabel counter (Perkin Elmer). At least three experiments were performed per condition and the averages and standard deviations of inhibition rates in each condition were evaluated to determine $\mathrm{IC}_{50}$ values using the GraphPad Prism software.

\subsection{Thermodynamic solubility in aqueous solution}

An equal volume of a mixture of $1 / 15 \mathrm{M}$ phosphate buffer $(\mathrm{pH} 7.4,0.5 \mathrm{~mL})$ and $\mathrm{EtOH}(0.5$ $\mathrm{mL})$, or $1 / 15 \mathrm{M}$ phosphate buffer $(\mathrm{pH} 7.4,1.0 \mathrm{~mL})$ was added to a compound in a vial. The suspension was then shaken for $48 \mathrm{~h}$ at $25{ }^{\circ} \mathrm{C}$, and undissolved material was separated by filtration. $m$-Cresol was added as an internal standard (final concentration: $0.05 \mathrm{mg} / \mathrm{mL}$ ) and the mixture was diluted in DMF and injected onto the HPLC column. The peak area ratio of the sample to the standard was recorded by UV detection at $254 \mathrm{~nm}$. The concentration of the sample solution was calculated using a previously determined calibration curve, corrected for the dilution factor of the sample.

\subsection{Molecular modeling}

Docking calculations for compound 11d were performed using a similar protocol in our previous research ${ }^{16}$ based on the crystal structure of the KSP-inhibitor complex (PDB ID: $3 \mathrm{ZCW}) .{ }^{27}$ The protonation states of the amino acid residues of KSP and the direction of the hydrogen atoms involved in the hydrogen bonds were assigned using the Protonate3D algorithm ${ }^{28}$ implemented in MOE. ${ }^{29}$ The $\alpha 4 / \alpha 6$ allosteric site was chosen from the binding sites detected by the MOE-SiteFinder module. Docking pose generation was performed applying pharmacophore restraint to form hydrogen bonds with Asn271 and Leu292. The 100 initial docked candidate poses were optimized by the MMFF94x forcefield ${ }^{30}$ and the pose with the lowest binding energy ( $\left.E_{\text {bind }}\right)$ estimated by the MM/GBVI method ${ }^{31}$ was adopted as 
the predicted binding mode.

\section{Acknowledgements}

This work was supported by Grants-in-Aid for Scientific Research, and Platform for Drug Discovery, Informatics, and Structural Life Science from MEXT, Japan. T. T. and R. M. are grateful for JSPS Research Fellowships for Young Scientists.

\section{Supplementary data}

Supplementary data associated with this article can be found, in the online version, at http://dx.doi.org/10.1016/j.bmc.2014.04.008.. 


\section{References and notes}

1 Miki, H.; Okada, Y.; Hirokawa, N. Trends Cell Biol. 2005, 15, 467.

2 Wordeman, L. Semin. Cell Dev. Biol. 2010, 21, 260.

3 Hirokawa, N.; Noda, Y.; Tanaka, Y.; Niwa, S. Nat. Rev. Mol. Cell Biol. 2009, 10, 682.

4 Kashina, A. S.; Baskin, R. J.; Cole, D. G.; Wedaman, K. P.; Saxton, W. M.; Scholey, J. M. Nature 1996, 379, 270.

5 Sawin, K. E.; LeGuellec, K.; Philippe, M.; Mitchison, T. J. Nature 1992, 359, 540.

6 Blangy, A.; Lane, H. A.; d'Herin, P.; Harper, M.; Kress, M.; Nigg, E. A. Cell 1995, 83, 1159.

7 Walczak, C. E.; Vernos, I.; Mitchison, T. J.; Karsenti, E.; Heald, R. Curr. Biol. 1998, 8, 903.

8 Mayer, T. U.; Kapoor, T. M.; Haggarty, S. J.; King, R. W.; Schreiber, S. L.; Mitchison, T. J. Science 1999, 286, 971.

9 Tao, W.; South, V. J.; Zhang, Y.; Davide, J. P.; Farrell, L.; Kohl, N. E.; Sepp-Lorenzino, L.; Lobell, R. B. Cancer Cell. 2005, 8, 49.

10 For a review, see: Jackson, J. R.; Patrick, D. R.; Dar, M. M.; Huang, P. S. Nat. Rev. Cancer 2007, 7, 107.

11 For a review, see: Matsuno, K.; Sawada, J.; Asai, A. Expert Opin. Ther. Patent 2008, 18, 253.

12 For a review, see: Sarli, V.; Giannis, A. Clin. Cancer Res. 2008, 14, 7583.

13 For a review, see: Rath, O.; Kozielski, F. Nat. Rev. Cancer 2012, 12, 527.

14 Oishi, S.; Watanabe, T.; Sawada, J.; Asai, A.; Ohno, H.; Fujii, N. J. Med. Chem. 2010, 53, 5054.

15 Takeuchi, T.; Oishi, S.; Watanabe, T.; Ohno, H.; Sawada, J.; Matsuno, K.; Asai, A.; Asada, N.; Kitaura, K.; Fujii, N. J. Med. Chem. 2011, 54, 4839. 
16 Takeuchi, T.; Oishi, S.; Kaneda, M.; Ohno, H.; Nakamura, S.; Nakanishi, I.; Yamane, M.; Sawada, J.; Asai, A.; Fujii, N. ACS Med. Chem. Lett. doi: 10.1021/m1500016j

17 Yan, Y.; Sardana, V.; Xu, B.; Homnick, C.; Halczenko, W.; Buser, C. A.; Schaber, M.; Hartman, G. D.; Huber, H. E.; Kuo, L. C. J. Mol. Biol. 2004, 335, 547.

18 Kaan, H. Y. K.; Ulaganathan, V.; Hackney, D. D.; Kozielski, F. Biochem. J. 2010, 425, 55.

19 Barsanti, P. A.; Wang, W.; Ni, Z.; Duhl, D.; Brammeier, N.; Martin, E.; Bussiere, D.; Walter, A. O. Bioorg. Med. Chem. Lett. 2010, 20, 157.

20 For a recent review, see: Ishikawa, M.; Hashimoto, Y. J. Med. Chem. 2011, 54, 1539.

21 Anderson, K. W.; Tundel, R. E.; Ikawa, T.; Altman, R. A.; Buchwald, S. L. Angew. Chem., Int. Ed. 2006, 45, 6523.

22 Avdeef, A.; Testa, B. Cell Mol. Life Sci. 2002, 59, 1681.

23 Jalalian, N.; Ishikawa, E. E.; Silva, L. F., Jr.; Olofsson, B. Org. Lett. 2011, 13, 1552.

24 Kwong, F. Y.; Buchwald, S. L. Org. Lett. 2002, 4, 3517.

25 Cava, M. P.; Levinson, M. I. Tetrahedron 1985, 41, 5061.

26 The incompatible results between the in vitro KSP inhibition and cytotoxicity could be attributed to the varied cell membrane permeability. The less solubility of compound $\mathbf{1 3}$ in aqueous solution may be disadvantageous to the in vivo studies.

27 Ulaganathan, V.; Talapatra, S. K.; Rath, O.; Pannifer, A.; Hackney, D. D.; Kozielski, F. J. Am. Chem. Soc. 2013, 135, 2263.

28 Labute P. Proteins, 2009, 75, 187.

29 MOE ver 2010.10, Chemical Computing Group Inc., Montreal, Canada.

30 Halgren T. A.; Nachbar R. B. J. Comput. Chem., 1996, 17, 587.

31 Labute P. J. Comput. Chem., 2008, 29, 1693. 
<smiles>FC(F)(F)c1ccc2c(c1)[nH]c1ccccc12</smiles><smiles>O=C1CCc2cc3c(cc2N1)[nH]c1cc(C(F)(F)F)ccc13</smiles><smiles>FC(F)(F)c1ccc2c(c1)[nH]c1cnccc12</smiles>

3a<smiles>NC(=O)Nc1ccc2c(c1)[nH]c1cc(C(F)(F)F)ccc12</smiles><smiles>O=C1CCc2cc(Nc3cccc(C(F)(F)F)c3)ccc2N1</smiles>

$5 a$<smiles>O=C1CCc2cc(Nc3cc(C(F)(F)F)ccn3)ccc2N1</smiles>

Figure 1. Structures of carbazole- and carboline-type (1-4) and diaryl amine-type (5, 6) KSP inhibitors.

(A)<smiles>FC(F)(F)c1ccc2c(c1)[nH]c1cnccc12</smiles><smiles>FC(F)(F)c1cccc(Nc2cccnc2)c1</smiles><smiles>FC(F)(F)c1ccc2c(c1)[nH]c1ccncc12</smiles><smiles>FC(F)(F)c1cccc(Nc2ccncc2)c1</smiles>

(B)<smiles>[R]c1ccc2c(c1)[nH]c1cc(C(F)(F)F)ccc12</smiles><smiles>[R]c1cccc(Nc2cccc(C(F)(F)F)c2)c1</smiles>

8a: $\mathrm{R}=\mathrm{NO}_{2}$

8b: $\mathrm{R}=\mathrm{NH}_{2}$

8c: $\mathrm{R}=\mathrm{NHCONH}_{2}$<smiles>[R]c1ccc2[nH]c3cc(C(F)(F)F)ccc3c2c1</smiles>

4d: $\mathrm{R}=\mathrm{NO}_{2}$

4e: $\mathrm{R}=\mathrm{NH}_{2}$

4f: $\mathrm{R}=\mathrm{NHCONH}_{2}$

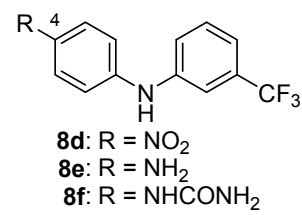

Figure 2. Design of novel KSP inhibitors 7, 8 with diaryl amine scaffolds.

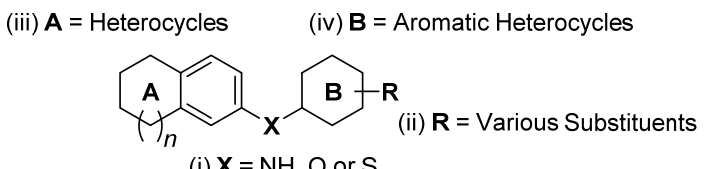

Figure 3. Strategy for the structure-activity relationship study of diaryl amine-type KSP inhibitors 


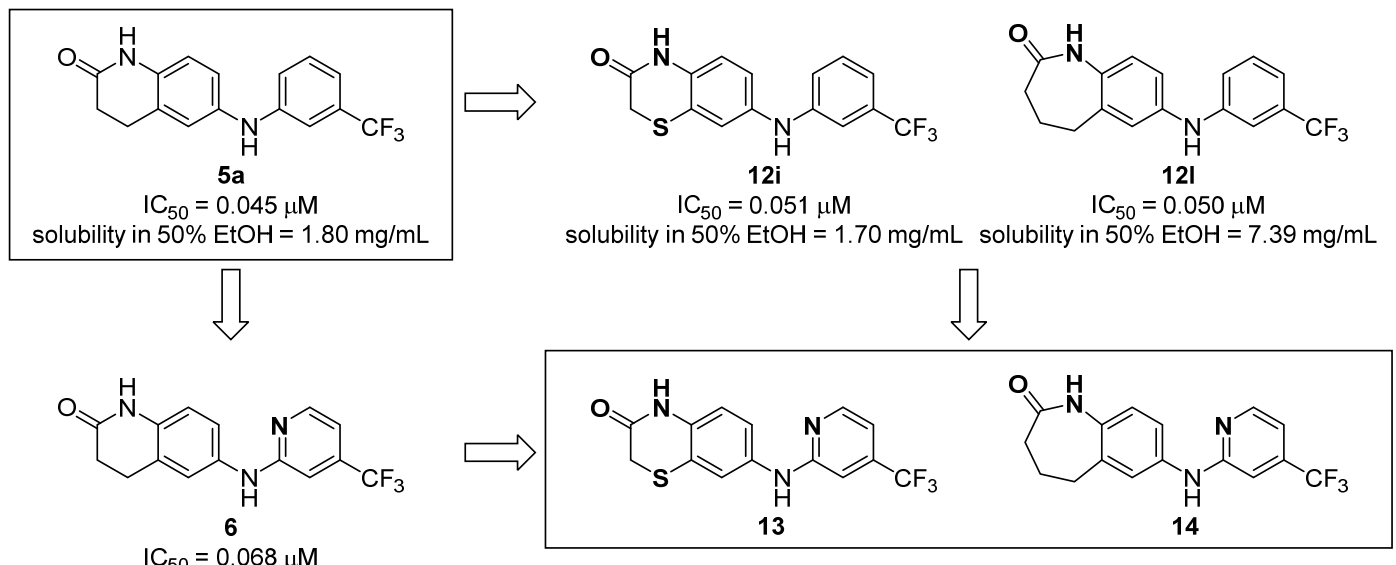

solubility in $50 \% \mathrm{EtOH}=3.51 \mathrm{mg} / \mathrm{mL}$

Figure 4. Design of novel diaryl amine-type KSP inhibitors 13 and 14.

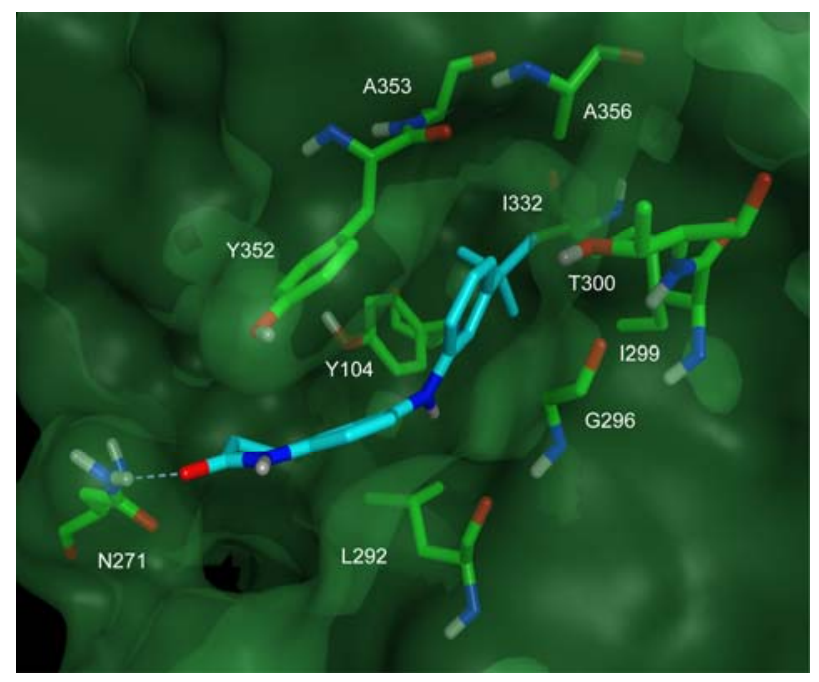

Figure 5. Plausible binding mode of diphenylamine 11d at the interface of helices $\alpha 4$ and $\alpha 6$. 


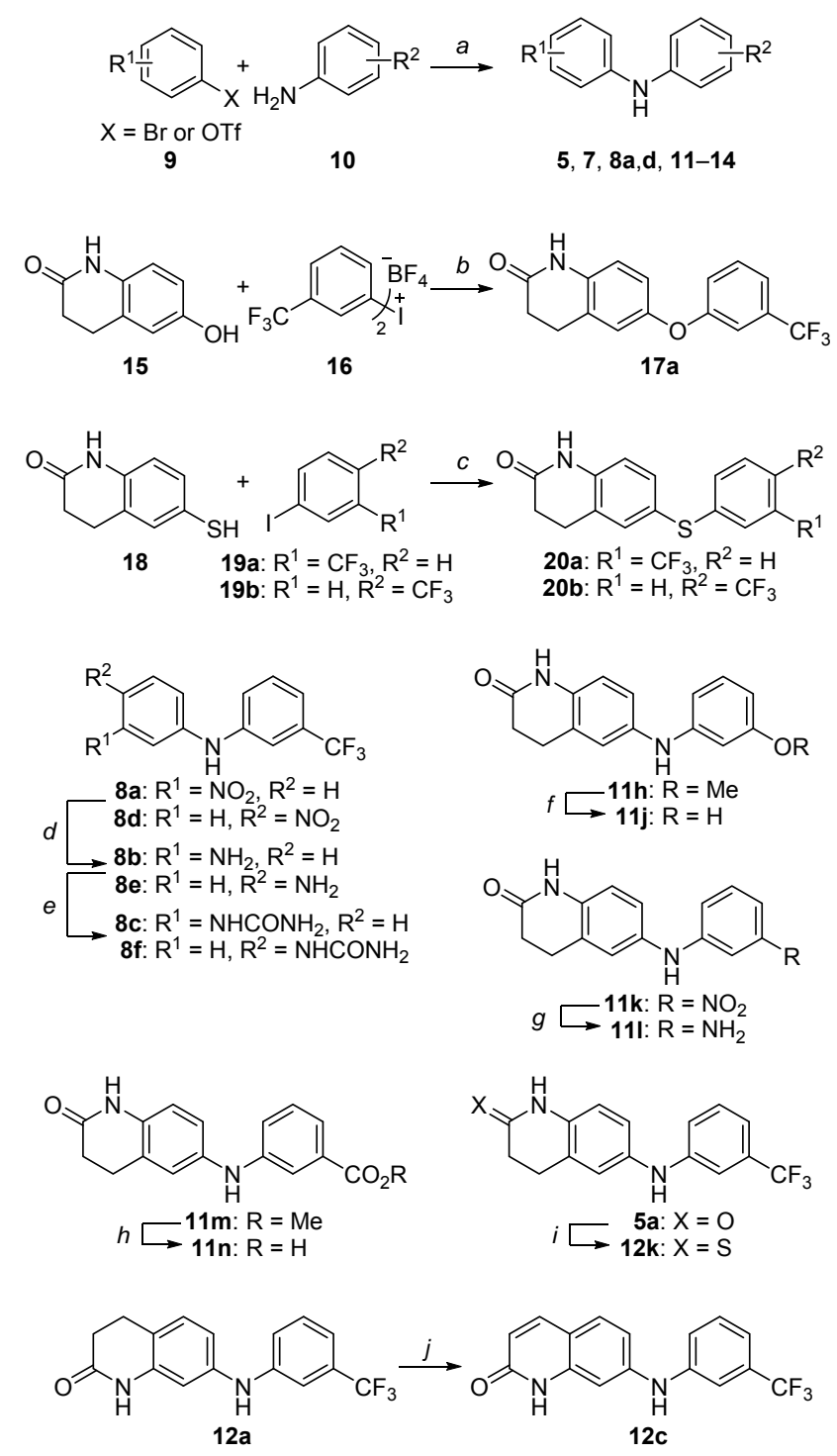

Scheme 1. Synthesis of diaryl amine derivatives. Reagents and conditions: (a) $\operatorname{Pd}_{2}(\mathrm{dba})_{3}$, biaryl phosphine ligand, $\mathrm{NaO} t$-Bu, toluene, $100{ }^{\circ} \mathrm{C}$; (b) $\mathrm{KO} t$-Bu, $\mathrm{DMF}, 40{ }^{\circ} \mathrm{C}$; (c) $\mathrm{CuI}$, ethylene glycol, $\mathrm{K}_{2} \mathrm{CO}_{3}$, 2-propanol, $80{ }^{\circ} \mathrm{C}$; (d) $\mathrm{Pd} / \mathrm{C}, \mathrm{HCO}_{2} \mathrm{NH}_{4}, \mathrm{EtOH}$, reflux; (e) $\mathrm{KOCN}$, $\mathrm{AcOH}, \mathrm{H}_{2} \mathrm{O}$, rt; (f) $\mathrm{BBr}_{3}, \mathrm{CH}_{2} \mathrm{Cl}_{2}$, rt; (g) $\mathrm{Zn}, \mathrm{AcOH}$, rt; (h) $\mathrm{LiOH} \cdot \mathrm{H}_{2} \mathrm{O}, \mathrm{MeOH}, \mathrm{H}_{2} \mathrm{O}, 50{ }^{\circ} \mathrm{C}$; (i) Lawesson's reagent, toluene, reflux; (j) $\mathrm{Pd}(\mathrm{OAc})_{2}, \mathrm{O}_{2}, \mathrm{AcOH}, 115^{\circ} \mathrm{C}$. 
Table 1. KSP inhibitory activities and thermodynamic aqueous solubility of diaryl amines with a pyridine ring and the related compounds.

\begin{tabular}{|c|c|c|c|c|}
\hline \multirow[b]{2}{*}{ compounc } & & \multirow{2}{*}{$\begin{array}{l}\text { KSP ATPase } \\
\mathrm{IC}_{50}(\mu \mathrm{M})^{a, b}\end{array}$} & \multicolumn{2}{|c|}{ solubility } \\
\hline & & & $50 \% \mathrm{EtOH}^{c}$ & phosphate buffer \\
\hline & 1 & 0.21 & 0.424 & $<1$ \\
\hline & $3 a$ & 0.052 & 0.472 & $<1$ \\
\hline & $3 b$ & 0.095 & 1.76 & 3.16 \\
\hline & $7 a$ & $>6.3^{d}$ & 14.3 & 10.8 \\
\hline & $7 b$ & $>6.3$ & 24.0 & 264 \\
\hline
\end{tabular}

${ }^{a}$ Inhibition of microtubule-activated KSP ATPase activity. ${ }^{b} \mathrm{IC}_{50}$ values were derived from the dose-response curves generated from triplicate data points. ${ }^{c}$ Solubility in an equal volume of EtOH and $1 / 15 \mathrm{M}$ phosphate buffer $(\mathrm{pH} 7.4) . \quad{ }^{d} \mathrm{IC}_{50}$ was $\approx 7.0 \mu \mathrm{M}$. 
Table 2. KSP inhibitory activities of diphenylamines with a nitro, amino or urea group and the related carbazoles.

$\begin{array}{llll} & \mathrm{R} & \mathrm{KSP} \text { ATPase } \\ \mathrm{IC} 50(\mu \mathrm{M})^{a, b}\end{array}$

${ }^{a}$ Inhibition of microtubule-activated KSP ATPase activity. ${ }^{b} \mathrm{IC}_{50}$ values were derived from the dose-response curves generated from triplicate data points. 
Table 3. KSP inhibitory activities of dihydroquinolinone derivatives.

\begin{tabular}{|c|c|c|c|}
\hline compound & & $X$ & $\begin{array}{l}\text { KSP ATPase } \\
\mathrm{IC}_{50}(\mu \mathrm{M})^{a, b}\end{array}$ \\
\hline & $5 \mathbf{a}$ & $\mathrm{NH}$ & 0.045 \\
\hline & $17 a$ & $\mathrm{O}$ & 2.0 \\
\hline & $20 a$ & $\mathrm{~S}$ & $>6.3$ \\
\hline & $5 \mathbf{b}$ & $\mathrm{NH}$ & 0.33 \\
\hline & $17 b$ & $\mathrm{O}$ & $>6.3$ \\
\hline & $20 b$ & $\mathrm{~S}$ & $>6.3$ \\
\hline & $5 c$ & & $>6.3$ \\
\hline
\end{tabular}

${ }^{a}$ Inhibition of microtubule-activated KSP ATPase activity. ${ }^{b} \mathrm{IC}_{50}$ values were derived from the dose-response curves generated from triplicate data points. 
Table 4. KSP inhibitory activities of diphenylamines with a 3-substituent or 3,5-substituents on the right-hand phenyl group.

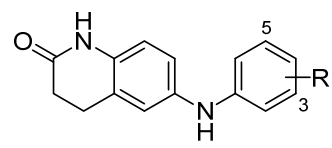

\begin{tabular}{|c|c|c|c|c|c|}
\hline $\mathrm{R}$ & & $\begin{array}{l}\text { KSP ATPase } \\
\mathrm{IC}_{50}(\mu \mathrm{M})^{a, b}\end{array}$ & $\mathrm{R}$ & & $\begin{array}{l}\text { KSP ATPase } \\
\mathrm{IC}_{50}(\mu \mathrm{M})^{a, b}\end{array}$ \\
\hline $3-\mathrm{CF}_{3}$ & $5 a$ & 0.045 & 3-OMe & $11 \mathrm{~h}$ & $>6.3$ \\
\hline $\mathrm{H}$ & $11 \mathrm{a}$ & $>6.3$ & $3-\mathrm{OCF}_{3}$ & $11 \mathrm{i}$ & 1.2 \\
\hline $3-E t$ & $11 b$ & 0.81 & $3-\mathrm{OH}$ & $11 \mathbf{j}$ & $>6.3$ \\
\hline $3-i-\operatorname{Pr}$ & $11 c$ & 0.43 & $3-\mathrm{NO}_{2}$ & $11 \mathrm{k}$ & 0.44 \\
\hline $3-t-\mathrm{Bu}$ & $11 d$ & 0.16 & $3-\mathrm{NH}_{2}$ & 111 & $>6.3$ \\
\hline 3,5-di-CF 3 & $11 \mathrm{e}$ & $>6.3$ & $3-\mathrm{CO}_{2} \mathrm{Me}$ & $11 \mathrm{~m}$ & $>6.3$ \\
\hline $3-\mathrm{Ph}$ & $11 f$ & $>6.3$ & $3-\mathrm{CO}_{2} \mathrm{H}$ & $11 n$ & $>6.3$ \\
\hline 3-OPh & $11 \mathrm{~g}$ & $>6.3$ & & & \\
\hline
\end{tabular}

${ }^{a}$ Inhibition of microtubule-activated KSP ATPase activity. ${ }^{b} \mathrm{IC}_{50}$ values were derived from the dose-response curves generated from triplicate data points. 
Table 5. KSP inhibitory activities of diphenylamines with a heterocycle on the left-hand phenyl group.

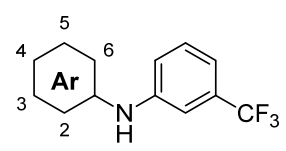

$\begin{gathered}\text { KSP ATPase } \\ \mathrm{IC}_{50}(\mu \mathrm{M})^{a, b}\end{gathered}$
$\mathbf{1 2 c}$

${ }^{a}$ Inhibition of microtubule-activated KSP ATPase activity. ${ }^{b} \mathrm{IC}_{50}$ values were derived from the dose-response curves generated from triplicate data points. 
Table 6. KSP inhibitory activities and physicochemical properties of diaryl amine derivatives 5a, $\mathbf{6}$,

$12 \mathrm{i}, 1,13$ and 14.

\begin{tabular}{|c|c|c|c|}
\hline & $5 \mathbf{a}$ & $12 \mathbf{i}$ & 12I \\
\hline $\begin{array}{l}\text { KSP ATPase } \\
\mathrm{IC}_{50}(\mu \mathrm{M})^{a, b}\end{array}$ & 0.045 & 0.051 & 0.050 \\
\hline $\begin{array}{l}\text { Solubility in } 50 \% \text { EtOH } \\
(\mathrm{mg} / \mathrm{mL})^{c}\end{array}$ & 1.80 & 1.70 & 7.39 \\
\hline $\begin{array}{l}\text { Solubility in phosphate buffer } \\
(\mathrm{pH} 7.4)(\mu \mathrm{g} / \mathrm{mL})\end{array}$ & $<1$ & $<1$ & $<1$ \\
\hline melting point $\left({ }^{\circ} \mathrm{C}\right)$ & 190 & 166 & 140 \\
\hline $\mathrm{Clog} \mathrm{P}^{d}$ & 4.2 & 4.0 & 4.4 \\
\hline \multirow[t]{2}{*}{ HPLC retention time $(\min )^{e}$} & 24.4 & 28.2 & 27.0 \\
\hline & 6 & 13 & 14 \\
\hline $\begin{array}{l}\text { KSP ATPase } \\
\mathrm{IC}_{50}(\mu \mathrm{M})^{a, b}\end{array}$ & 0.068 & 0.035 & 0.050 \\
\hline $\begin{array}{l}\text { Solubility in } 50 \% \mathrm{EtOH} \\
(\mathrm{mg} / \mathrm{mL})^{c}\end{array}$ & 3.51 & 0.669 & 4.82 \\
\hline $\begin{array}{l}\text { Solubility in phosphate buffer } \\
(\mathrm{pH} 7.4)(\mu \mathrm{g} / \mathrm{mL})\end{array}$ & 6.12 & 1.11 & 8.07 \\
\hline melting point $\left({ }^{\circ} \mathrm{C}\right)$ & 177 & 217 & 185 \\
\hline $\mathrm{Clog} \mathrm{P}^{d}$ & 3.4 & 3.2 & 3.6 \\
\hline HPLC retention time $(\min )^{e}$ & 7.0 & 13.8 & 10.8 \\
\hline
\end{tabular}

${ }^{a}$ Inhibition of microtubule-activated KSP ATPase activity. ${ }^{b} \mathrm{IC}_{50}$ values were derived from the dose-response curves generated from triplicate data points. ${ }^{c}$ Solubility in $50 \%$ EtOH [an equal volume of EtOH and 1/15 M phosphate buffer $(\mathrm{pH} 7.4)] .{ }^{d} \mathrm{CLogP}$ values were calculated with ChemBioDraw Ultra 12.0. ${ }^{e}$ HPLC analysis was carried out on a Cosmosil 5C18-ARII column (4.6 $\times 250 \mathrm{~mm}$ ) and the material eluted by a linear $\mathrm{MeCN}$ gradient $(30-70 \%$ over $40 \mathrm{~min})$ in $0.1 \% \mathrm{TFA}$; flow rate of $1 \mathrm{~mL} / \mathrm{min} .{ }^{a}$ Inhibition of microtubule-activated KSP ATPase activity. ${ }^{b} \mathrm{IC}_{50}$ values were derived from the dose-response curves generated from triplicate data points. ${ }^{c}$ Solubility in $50 \%$ EtOH [an equal volume of EtOH and 1/15 M phosphate buffer ( $\mathrm{pH}$ 7.4)]. ${ }^{d} \mathrm{CLogP}$ values were calculated with ChemBioDraw Ultra 12.0. ${ }^{e} \mathrm{HPLC}$ analysis was carried out on a Cosmosil 5C18-ARII column $(4.6 \times 250 \mathrm{~mm})$ and the material eluted by a linear $\mathrm{MeCN}$ gradient $(30-70 \%$ over $40 \mathrm{~min}$ ) in $0.1 \% \mathrm{TFA}$; flow rate of $1 \mathrm{~mL} / \mathrm{min}$. 
Table 7. Inhibitory effects on cell proliferation of diaryl amine-type KSP inhibitors toward A549, HCT-116 and MCF-7.

\begin{tabular}{cccc}
\hline \multirow{2}{*}{ compound } & \multicolumn{3}{c}{$\mathrm{IC}_{50}(\mu \mathrm{M})^{a}$} \\
\cline { 2 - 4 } & A549 & HCT-116 & MCF-7 \\
\hline $\mathbf{5 a}$ & 4.2 & 8.9 & 11 \\
$\mathbf{6}$ & 2.5 & 4.4 & 8.0 \\
$\mathbf{1 2 i}$ & 4.1 & 6.8 & 6.5 \\
$\mathbf{1 2 1}$ & 4.5 & 5.7 & 3.9 \\
$\mathbf{1 3}$ & 1.5 & 2.6 & 2.8 \\
$\mathbf{1 4}$ & 5.0 & 6.5 & 9.1 \\
\hline
\end{tabular}

${ }^{a} \mathrm{IC}_{50}$ values were derived from the dose-response curves generated from triplicate data points. 